\title{
Case Study on Distribution of Responsibilities for the Civil Case of False Card Fraudulent Trading
}

\author{
Yimeng Xu \\ Shandong University of Finance and Economics, Jinan, China \\ Email:13256105172@sina.cn
}

Received 7 June 2016; accepted 19 July 2016; published 22 July 2016

Copyright @ 2016 by author and Scientific Research Publishing Inc. This work is licensed under the Creative Commons Attribution International License (CC BY). http://creativecommons.org/licenses/by/4.0/ (c) (i) Open Access

\begin{abstract}
In recent years, bank card has come more and more necessary in people's daily life, however it also has the hidden risk. Who should be responsible for the loss when the bank cards in our hand are used by criminals as a tool of accumulating money? In this paper, we will carry out case studies to find a solution plan on the distribution of responsibilities in the civil case of false card fraudulent trading by analyzing the current situation of distribution of the responsibilities.
\end{abstract}

\section{Keywords}

False Card Fraudulent Trading, Civil Responsibility, Distribution of Evidential Burden

\section{Introduction}

In 2015, the amount of bank cards issued by all of the major Chinese banks had reached 5.252 billion, which meant each person had 4 bank cards in average. All kinds of bank cards have brought great convenience to our lives, together with great security risk in the meantime. In recent years, various crimes caused by bank cards are emerging in an endless stream, which has brought great loss to our nation and people. The false card fraudulent trading which will be discussed in this paper is one of the crimes. It will violate the penal law undoubtedly and the offender will be punished according to the penal code. But the civil responsibility dispute caused by the false card fraudulent trading should also be taken seriously.

As to the false card fraudulent trading, the criminals obtain the magnetic strip information of the cardholder's bank card by various illegal means and forge an identical card by the magnetic strip information. Then the criminals will use the forged card to withdraw cash or transfer money at the bank counter or through ATM machines, or they will consume by swiping the forged card on POS machine. Thus behaviors will cause capital loss 
of the real cardholders or financial institutions.

In this paper, the trial practices in different local courts will be studied and reasonability and disadvantages of various distribution of evidential burden will be analyzed in the case of false card fraudulent trading in order to find out a solution to distribution of responsibilities for the false card fraudulent trading [1].

\section{The Courts' Current Responsibility Distribution Situation of the False Card Fraudulent Trading}

1) The main responsibility for the false card fraudulent trading existence and its more and more appearance in different places lie with the issuing bank. At present, cards issued by our country's banks still have a large number of magnetic stripe cards, for which the stored information in magnetic strips is less, the technology is simple and security performance is not enough, so the stored information in magnetic strips is easily read by others. The deposit in an account becomes less due to criminal's acts, and it caused economical loss to the real cardholders and financial institutions. Who should be responsible for the loss? How to distribute the burden of proof? Due to the lag of legislation, there is no a consistent legal rule. From the current judicial practices, there are also different verdicts nationwide [2].

In the first case, the burden of proof is on the cardholder since the court decides the cardholders take all of the responsibilities and the issuing banks don't need to take responsibility. Related legal basis can be found in the first paragraph of article sixty-four in Civil Procedure Law of the People's Republic of China and Article 2 of the Evidence Regulation.

Wang Xiaoyue's dispute with Agricultural Bank of China Ltd., Ye county branch on bank cards belongs to that case. Wang Xiaoyue applied for a bank card in the Agricultural Bank of China Ltd., Ye county branch. After opening an account, there appears many intercity consumptions and E-bank consumptions to the account from June 2013 to October 2013. And according to the bank account details, it appears many times that more than one consumption happened in one day and frequent trades were conducted in short time. So Wang Xiaoyue believes that her bank deposit was stolen and the bank fails to protect depositor's benefits, so she lodged a complaint. The court believes that Wang Xiaoyue should protect the card and password as the cardholder after opening the account in the first-instance judgment. Although Wang Xiaoyue can prove that her bank deposit was reduced, however, she could not prove that the bank has fault in the regulation. So the court decides that the cardholder should take all the responsibility while the issuing bank needn't to take responsibility. The ground of decision is to respect the validity of bank form contract that the cardholder should safeguard their card and password and update the password in time in order not to be stolen. All the bank card consumptions with similar password would be taken as the cardholder themselves' consumptions or the cardholder authorized consumptions. When the cardholders make transactions, the bank card issuers deal with electronic records which is valid certificate for the transaction. The cardholder should take all of the responsibilities for the loss caused by password stolen, because they failed to keep the card and password safe. So from this point of view, the cardholder bears all the duty while the issuing bank needn't [3].

2) In the second case, all of the responsibility is assigned to the issuing bank instead of the cardholder. The legal basis is in the Article 5 of the Evidence Regulation. The judgment is based on that the issuing bank failed to fulfill a secure and confidential contract together with bundled duty and to recognize the false card, also the bank could not prove the cardholder has serious fault in letting out card number and password which leads to deposit stolen, and the bank could not prove that it is the cardholder' intended act or a co-conspirator of the crime and so on.

Here is another example that Mr. Xu has the bank card dispute with Guangxi guilinlijiang rural cooperative bank. Mr. Xu applied for a bankbook from Guangxi guilinlijiang rural cooperative bank on July $2^{\text {nd }}$, 2009, then he received SMS notifications about consecutive withdrawing money at the time of a quarter to eight pm on April $19^{\text {th }}$, 2012. So Mr. Xu withdrew all the deposit in the bank card and called the police and then sued the bank in a court for its failed responsibility to secure the bank card. The plaintiff proved that the bankbook and the bank card were not lost when the deposit was stolen and he himself was not at the place where the deposit was withdrawn. The court thought that the plaintiff had completed the burden of proof while the bank could not prove that it has no fault in its administration. Thus in this case, the court thought that the bank should be responsible for not able to give evidence, so the bank should bear all the loss [4].

3) The third case is the most widely used in juridical practice at present, in which both the issuing bank and 
the cardholder should bear the burden of proof. The legal basis is in the first paragraph of Article sixty-four in Civil Procedure Law of the People's Republic of China and Article 2 and Article 5 of the Evidence Regulation. The court asked both the plaintiff and the defendant bear due responsibility according to the fulfillment situation of their burden of proof. In practice, the court divided the responsibility into two parts, including twenty to eighty, thirty to seventy, fifty to fifty and so on. On one hand, the issuing bank could not prove that the loss of the card number and password was not its fault, and ATM machine could not identify the true and false bank card, and there is flaw in the bank security system, so the issuing bank should bear some responsibility. On the other hand, the cardholder could not prove that the issuing bank has fault in letting out the bank card password and other information, and also could not prove that he has secured the bank card well, so the cardholder also should bear some responsibility for he failed to fulfill the duty of care.

In the case of Wang Yunxia's dispute with Agricultural bank of China co., LTD., yichuan branch, both the issuing bank and the cardholder was assigned responsibility. In this case, Wang Yunxia applied for the agricultural bank of China Jin Sui debit card in December 2012 by her ID card. Wang Yunxia set a password for her card following the procedure of the bank. But the deposit was withdrawn many times with a large amount of money. At the same day, Wang Yunxia reported to Yichuan county public security bureau with her bank card. Besides, the court also received a related judgment that the people's court of Yichuan county affirmed that defendants Liu Pengfei and Zhang Canpo installed a modified "Kara” machine in Zhang Canpo's 713 office of Yuan Yitong Advertisement co., LTD. in the seventh floor of Yichuan county central department, which leads to Wang Yunxia's stolen deposit. So Wang Yunxia required Agricultural bank of China Co., LTD., Yichuan branch to pay for the withdrawn deposit together with the handling charge. The court supported Wang Yuxia's requirement. But undeniably, Wang Yuxia didn’t pay enough attention when she swiped her card on the "Kara" machine which was stalled by Zhang Canpo illegally in the seventh floor of central department. Thus Wang Yuxia also has responsibility in letting out her bank card information and Agricultural bank of China co., LTD., yichuan branch's responsibility should be lessened suitably. As a result, Wang Yuxia bear 10\% of the loss while Agricultural bank of China co., LTD., yichuan branch bear $90 \%$ of the loss according to the court's decision.

\section{Problems Caused by False Card Fraudulent Trading and the Reason of Its Existence}

Firstly, courts in different places have different burden of proof distribution, so there is a shortage of a national unified judicial judgment standard which leads to different judgments on the same case. What's more, the judgments were changed due to the second trial judge's different burden of proof distribution after the appeal of trial in many cases. It will do harm to the stability and predictability of the law which will bring adverse effects on the construction of our country under the rule of law [5].

The reasons of this problem can be summarized into two. The first reason is that there is no law or regulation explaining the rights and duty of parties in the false card fraudulent trading. That is law vacancy which will easily cause different opinions on the same problem, because of judicators' different experience and legal knowledge. The second reason is news ballyhoos and social opinions' effects on cases handling results. Nowadays, everyone has one or more bank cards, and problems about it can cause extensive attentions. Then fueled by the media, it always gives rise to sensational social effects. So the judicators have to take the public opinions into consideration.

Secondly, we can draw a conclusion from the above cases that the results of the cases depend mainly on the judicators' burden of proof distribution. Who should bear more burden of proof in the judicators' opinion will lose the lawsuit and the other side will win. This phenomenon connects with the second problem that the evidence is difficult to be collected. It is difficult to provide evidence and identify the false card. There are two problems need to be proved by evidence in dealing with false card fraudulent tradings. One is to identify the card is false or true when the transaction occurs. The other problem is to decide whether it's the cardholder or the issuing bank let out the information such as the card number, password and so on. If we can collect evidence by the cardholder's evidence of his position and the card position when the transaction occurs, then the second problem is in a deadlock. Because every cardholder thinks he has protected his bank card well in practice. As the only person who knows the password, the cardholder has fault in the password stolen, but the issuing bank almost could not give evidence that the cardholder' fault is the major fault in the case.

And there are three reasons for this problem. First, criminals use more and more secrete means to steal information. In the past, criminals install a pinhole spy camera or a card reader in ATM machine or other bank 
equipment. In recent years, criminals install a card reader device in merchant's POS machines (such as the Kara machine in the case of Wang Yuxia's). Compared with the first way, it is more secret and more difficult to collect evidence if criminals install a card reader device in merchant's POS machines. Second, the unauthorized card swiping always happens in cross-system and cross-border which make the evidence become more difficult to be collected. Third, banks usually refuse the cardholders' request on video surveillance in order to protect the banks themselves, or they will take excuses that the monitor is broken or imaging data was covered by other information or the information is beyond the expiration date. So the cardholders could not collect necessary evidence.

\section{The Solutions to False Card Fraudulent Tradings}

First, from the above cases we can know that the most fundamental way is to establish a unified system of distribution of evidential burden from the level of national legislation in order to avoid the situation of different results on the same cases and protect the dignity and stability of law.

Second, the courts are requested to keep a neutral position in the judicial regime. The judge should not give heavier burden of proof to the cardholders in the aim of protecting the state property. It also should not think that the banks are absolute powerful so heavier burden of proof should be given to the bank. The court should consider both the parties' actual situations, together with some special cases' situations, evidence materials, legal relations and so on. Only after analyzing all of the conditions can the court distribute the burden of proof and make a just sentence.

Third, as to the banks, it is their duty to actively upgrade bank cards and maintain and upgrade the security system. The banks should take research on bank cards and use chip card instead of magnetic stripe card and to effectively safeguard the interests of depositors.

At last, the social public should strengthen their consciousness on protecting information security and improve their financial quality and self-defence. It is also an effect way to pay much attention in order to avoid letting out password information.

\section{Conclusion}

In fact, the false card fraudulent trading is not the only disputes between the depositors and banks. There are many other problems such as the deposits increase or lessen due to the bank machines' bugs or the banks' error in payments. But just like the false card fraudulent trading, there are no clear legal norms, then added by local protection effect and the pressure of public opinion, improper burden of proof distribution happens widely and intensively. In practice, both the problem of false card fraudulent trading and other talked problems depend on integrity of China's legal construction. Although China has established a legal system with Chinese characteristics, an integrity legal system needs a long process. We should work hard together in the process.

\section{References}

[1] Yang, L.X. and Wang, L.F. (2015) The Liability of the Damage by Fraudulent Use of Credit Card from the Perspective of Law.

[2] Zhang, J. (2015) Discussion on Quasi-Possession's Application in Deposit Contract in Bank’s View to the Third Person's “Good-Faith”. Legal System and Society, 4.

[3] Peng, J.H., Pan, F. and Li, X.H. (2012) Distribution of Evidential Burden and Responsibilities for the Civil Case of False Card Fraudulent Trading. Rule of Law Forum, 3.

[4] Cheng, S. and Huang, H.W. (2012) Research on Bank’s Duty to Protect Depositor's Interest—In the Case of a Depositor's Win to the Bank about Stolen Deposit.

[5] Sun, X.L. Discussion on Bank's Duty for Security—In the Case of Steal by a Clone Bank Card. Journal of Commerce of Tianjin University, 2. 


\section{Submit or recommend next manuscript to SCIRP and we will provide best service for you:}

Accepting pre-submission inquiries through Email, Facebook, LinkedIn, Twitter, etc.

A wide selection of journals (inclusive of 9 subjects, more than 200 journals)

Providing 24-hour high-quality service

User-friendly online submission system

Fair and swift peer-review system

Efficient typesetting and proofreading procedure

Display of the result of downloads and visits, as well as the number of cited articles

Maximum dissemination of your research work

Submit your manuscript at: http://papersubmission.scirp.org/ 